Proc. Indian Acad. Sci. (Earth Planet. Sci,), Vol. 94, No. 1, March 1985, pp. 57-70.

(C) Printed in India.

\title{
Petrology of thermally metamorphosed pelitic rocks in the Champawat Area, Kumaun Himalaya
}

\author{
BRIJRAJ K DAS \\ Centre of Advanced Study in Geology, Punjab University, Chandigarh 160014, India
}

MS received 27 May 1983; revised 5 September 1984

\begin{abstract}
In the Champawat area, Kumaun Himalaya, greenschist facies regionally metamorphosed rocks viz chlorite-phyllite and schist have been subjected to thermal metamorphism due to emplacement of batholithic granite/granodiorite body. As a consequence, biotite, garnet, andalusite, fibrolite, sillimanite and perthite minerals have formed in the contact rocks. The conspicuous absence of cordierite and staurolite reported from such aureole rocks is due to higher $\mathrm{FeO} / \mathrm{MgO}$ ratio of the bulk rock composition in the former while the absence of staurolite is due to low $\mathrm{Al}_{2} \mathrm{O}_{3} / \mathrm{FeO}+\mathrm{MgO}$ ratio in the schists. AFM diagram demonstrates that in muscovite-bearing schist, the bulk composition of chlorite-and cordierite-bearing rocks are restricted to low $\mathrm{FeO} / \mathrm{MgO}$ side and thus the restricted occurrence of former and the absence of latter in the contact rocks of the area. This is further evident from the common occurrence of almandine-rich garnet in the rocks.
\end{abstract}

Keywords. Pelitic; hornfels; Champawat; Hornblende-hornfels facies; grano-diorite; batholith.

\section{Introduction}

The batholithic-sized granodioritic body out-cropping in Champawat area has attracted the attention of many geologists (e.g. Kharkwal 1951; Valdiya 1962; Sharma and Awasthi 1980). All of them considered it to be magmatic in origin, but none recorded the evidence of contact metamorphism in this region. During the present investigation the development of typical pelitic hornfels (Das and Singh 1981) occurring in the granodiorite body, though sporadically has been recorded. Curiously, no visible thermal aureole around the main batholith is observed, which may be either concealed or eroded as the aureole tend to be confined to roof portions of the country rock. Moreover, the hornfelses typically consist of biotite, garnet and andalusite assemblage but the cordierite is absent and staurolite is rare in these rocks. This shows departure from the common assemblages reported from similar areas elsewhere. In this paper an attempt has been made to discuss the petrology and the paragenesis of mineral assemblages of the hornfels of the area and to estimate the PT condition of metamorphism.

\section{Geological setting}

The Champawat area consist predominantly of igneous and low-grade metamorphic rocks. The igneous variety constitutes a large batholithic body ( $6 \mathrm{~km}$ width), extending laterally from Kali to Mornaula through Dhunaghat and Devidhura (Valdiya 1962; Misra and Sharma 1967; Sharma and Awasthi 1980). The northern contact of the body 
is remarkably sharp, being overlain abruptly by phyllites and quartzites of Gumalikhet Formation, along a dislocation having a northwardly dip, while the southern contact is gradational and flanked by augen gneiss, feldspathic schist associated with biotite schist, garnet-mica schist and micaceous quartzite of Gorakhnath Formation (figure 1).

The spotted hornfels is exposed towards the southern contact of batholith about $6 \mathrm{~km}$ south of Champawat and extends further in strike direction about $2 \mathrm{~km}$ from Banlekh to Dhaun on Tanakpur road. The pelitic and semi-pelitic rocks recrystallized to spotted hornfels of the type described by Compton (1960). Besides the hornfels, xenolith of fine-grained dark grey, biotite-rich country rocks of the size from a fraction of a centimetre to those measurable in metres are common, which according to Valdiya (1980) may represent roof pendents.
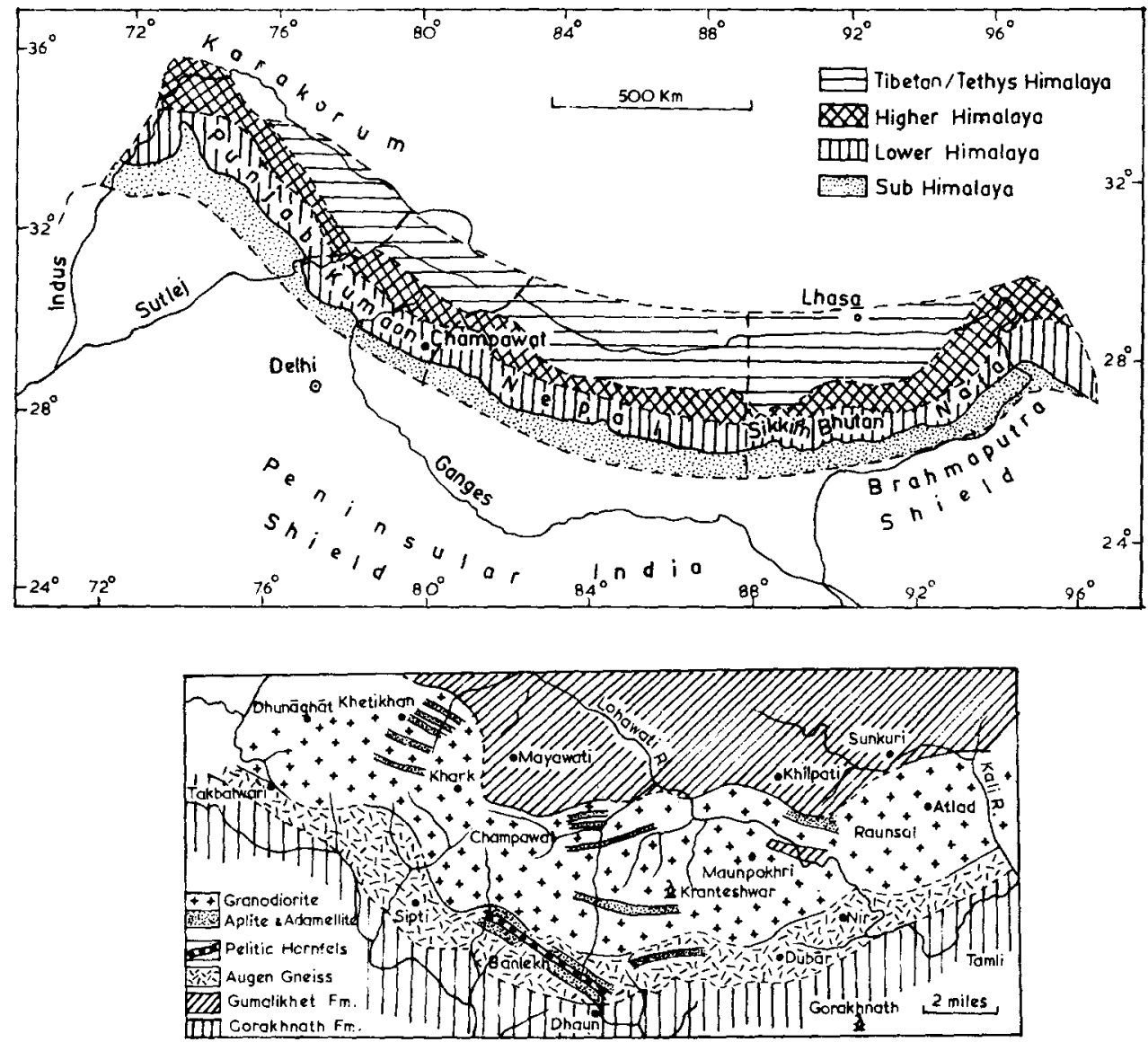

Figure 1. Geological sketch map of the Champawat area (lower) showing expanse of granodiorite and the outcrops of hornfelses exposed near Banlekh and Dhaun. The bands of the late magmatic adamellite and aplitic granite is also shown (modified after Valdiya 1980). The map above shows the location of Champawat in Kumaun Himalaya (after Gansser 1964). 


\section{Petrographic characters}

The pelitic hornfelses are fine-to medium-grained, light to dark greyish coloured spotted rocks. The semi-pelitic variety is very hard and compact. The spots are $0.5-1 \mathrm{~mm}$ in elongation, oval or rounded in shape and irregularly scattered or segregated in some parts of the rock. The spots are mostly of poikiloblastic chlorite and/or segregation of phyllosilicates. In thin section it exhibits hornfelsic texture defined by decussate arrangement of scaly or short poikiloblastic biotite and less commonly white mica. The reddish brown sieved biotite is sub-parallel to $S_{1}$ foliation or irregularly disposed in the matrix of the rock (figure $2 a$ ). In some thin sections the $S_{1}$ foliation marked by sericite and scaly chlorite is microfolded or crenulated together with the poikiloblastic chlorite, which represents the aureole chlorite developed during thermal metamorphism (figure 2b). Such chloritic mass represents the spots over which scaly biotite, less commonly muscovite, often sieved and highly spongy garnet often with polygonal outline, are grown (figure $2 \mathrm{c}$ ).

Besides the fine mica and chlorite of phyllite, small sieved flakes of muscovite and aggregates of scaly muscovite overprinting the groundmass are aureole muscovite. Biotite also occurs in thin layers or in streaky form some times replacing chlorite, and is highly sieved with quartz and opaques and encloses poikiloblastic andalusite (figure $2 \mathrm{~d}$ ). The textural relation suggests that the crystallization of andalusite is related to chlorite and white mica. The associated biotite may be a product phase.

Large, pinkish, poikiloblastic and highly sieved, with quartz and opaques and skeletal garnet overprint the groundmass, and shows replacive relation with the streaky biotite, which also occurs as relict in the former (figure $2 \mathrm{c}$ ). The garnet of mica schist is deformed showing syntectonic rotational trails (si) while the aureole garnet does not show such a feature. The textural relation of garnet in the latter shows its crystallization during a static thermal phase post dating the deformation.

Staurolite is rare and embedded in a mesh of randomly oriented muscovite film and traces of relicts of biotite and grains of opaques are scattered in the mesh of muscovite (figure 2e). It is associated with the aggregate or bundle of needle sillimanite without any evidence of resorption or replacement (figure $2 \mathrm{f}$ ). The mode of occurrence indicates that the staurolite and white mica formed by rehydration reaction of andalusite and biotite.

Andalusite is a common aureole mineral of the pelitic hornfels and occurs in poikiloblastic, spongy and skeletal form (figures $3 a, b$ ). It is often sieved with coarse quartz grains of the size forming the groundmass (figure $2 \mathrm{~d}$ ). Inclusion of opaques and association with biotite streaks are common (figures $3 \mathrm{a}, \mathrm{b}$ ) and the latter partly or completely surrounds it. In a few thin sections andalusite is altered to shimmer and the relict of former occurs in the latter (figures $3 c, d$ ). In those rocks which occur near the contact, the sillimanite needles protrude the andalusite crystals and partly replace it (figure 3e) indicating partial resorption. Andalusite is faintly pinkish and pleochroic (the pinkish shade is deeper at certain spots of the same crystal).

Sillimanite occurs in three different forms such as fine needles fringing the porphyroblastic minerals or included in them; as robust needles or prismatic crystals occurring in a few thin sections of the rocks from the vicinity of magmatic body, in which biotite is intensely fibrolitized and as coarse prismatic sillimanite (figure $3 \mathrm{f}$ ). The biotite in such cases is bleached and its relict commonly occurs in sillimanite prism (figure 3f). Such needles trespass in adjacent quartz, andalusite, plagioclase and scarcely 

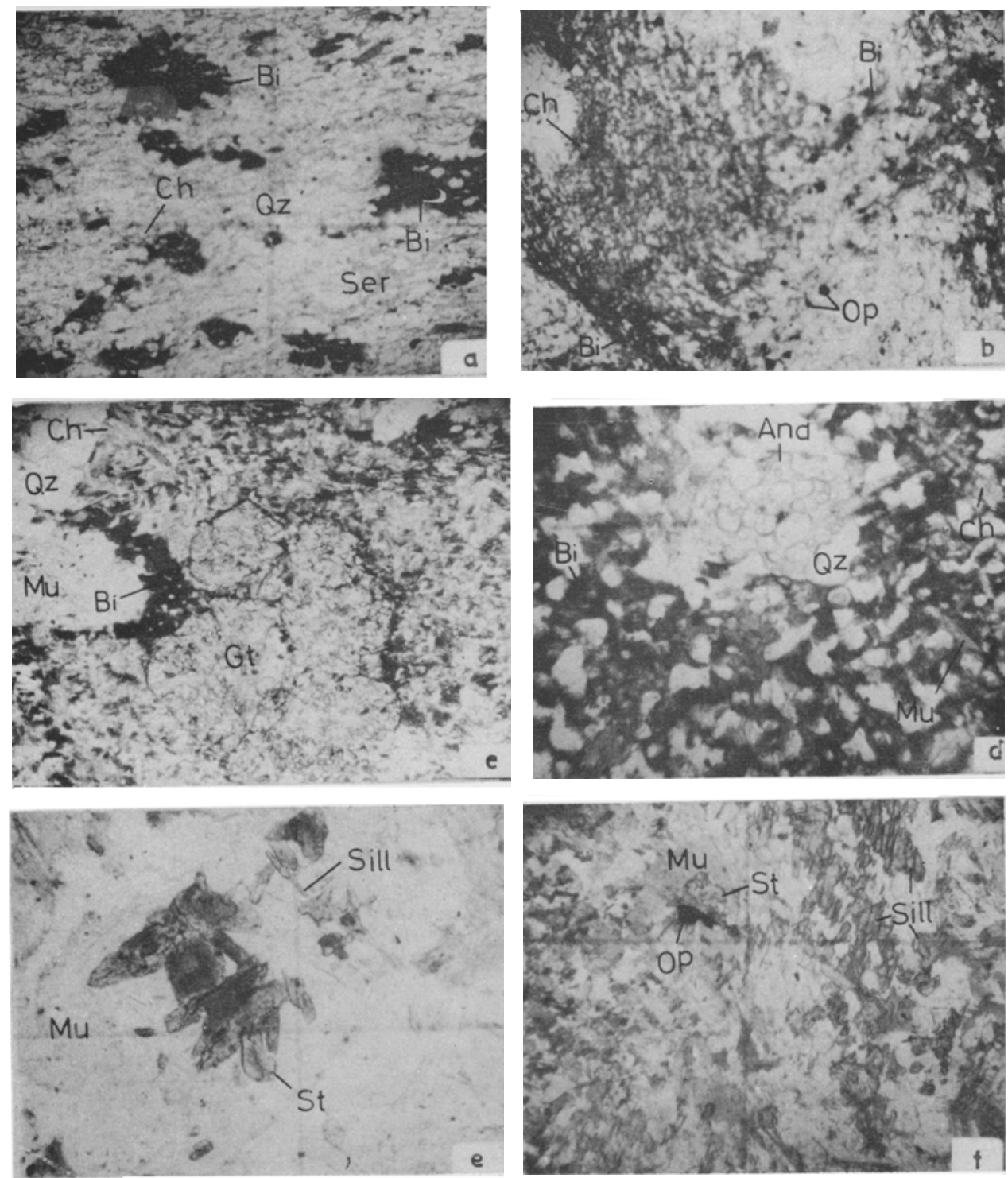

Figures 2a-f. a. Low-grade phyllite showing foliation $\left(\mathrm{S}_{1}\right)$ defined by the specks of sericite (Ser) and chlorite (Ch). Note the subsequent development of highly sieved aureole biotite (Bi) porphyroblast imprinting the groundmass. b. Highly sieved and patchy chlorite $(\mathrm{Ch})$ showing deformation and is folded along with the foliation $\left(S_{1}\right)$. Note the fine grains of opaques ( $\mathrm{Op}$ ) and streaky biotite $(\mathrm{Bi})$ associated with it. c. Highly spongy garnets $(\mathrm{Gt})$ with polygonal outline grown over the chlorite $(\mathrm{Ch})$, biotite $(\mathrm{Bi})$ and sericite $(\mathrm{Ser})$ matrix. Note the segregation of small laths of muscovite $(\mathrm{Mu})$ containing inclusions of opaques $(\mathrm{Op})$ and replacing biotite (Bi). d. Poikiloblastic andalusite (And) overprinting the ground mass of quartz $(\mathrm{Qz})$, chlorite $(\mathrm{Ch})$ and muscovite $(\mathrm{Mu})$. It is almost completely surrounded by the streaky highly sieved biotite (Bi). Notice the hornfelsic texture and decussate structure. e. Prismatic crystals of zoned staurolite (St) intergrown with late muscovite film $(\mathrm{Mu})$. The core is darker in colour than the periphery. Note the needle sillimanite (Sill) also intergrown with muscovite (Mu). f. Needle and prisms of sillimanite (Sill) intergrown with late muscovite $(\mathrm{Mu})$ and/or biotite (Bi) streaks. Also notice the small grains of staurolite $(\mathrm{St})$ grown over biotite $(\mathrm{Bi})$ associated with opaques $(\mathrm{Op})$. (All figures, $\times 100$, plane-polarised light). 

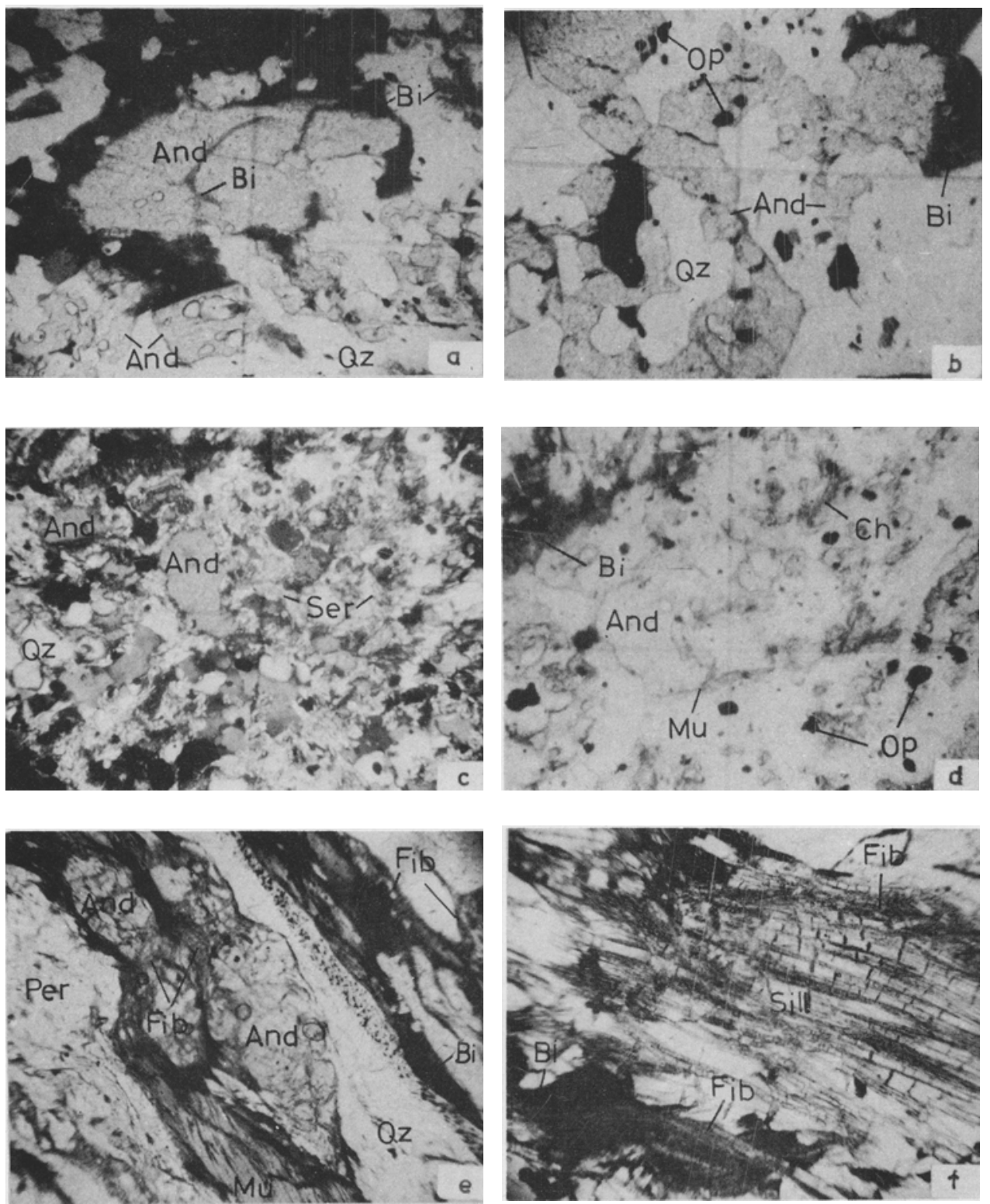

Figures 3a-f. a. Idioblastic crystals of andalusite (And) which are often sieved with quartz (Qz) and closely associated with biotite (Bi) the latter also occurs along the cracks of andalusite. The crystals are over printing the groundmass. b. Skeletal andalusite (And) grown over the groundmass and at places replacing streaky biotite $(\mathrm{Bi})$ and contains inclusion of opaques (Op). c. Andalusite (And) is altered to shimmer of sericite (Ser) in which relict of former occurs here and there. Also note the deformed quartz grains (Qz) showing undulatory extinction. d. Xenoblastic crystals of andalusite (And) fringed by the thin film of muscovite $\mathrm{(Mu}$ ) and the latter is replacing the former. Note the streaky biotite $(\mathrm{Bi})$ and chlorite $(\mathrm{Ch})$ in the matrix. e. Andalusite (And) enclosed within biotite ( $\mathrm{Bi}$ ) which is fibrolitized and replacing the former. Biotite $(\mathrm{Bi})$ also replaces muscovite $(\mathrm{Mu})$ and perthite (Per) replacing fibrolitized (FiB) biotite (Bi). $\mathrm{f}$. The bundles of needle sillimanite (Sill) changing to prismatic form and contains streak of biotite (Bi) especially along the fractures which are vertical. Note that fibrolite (Fib) changing to sillimanite (Sill) and biotite (Bi) is fibrolitized. (All figures $\times 100$, plane-polarised light). 
muscovite indicating its later crystallization. Sillimanite pseudomorph after andalusite has been observed and a similar character has been noticed by Chinner (1961) and Green (1963) in Scottish Highlands and Northern New Hampshire respectively.

Among the feldspars perthitic microcline and/or microcline are common though plagioclase also occurs in most of the rocks and is often sieved with quartz and opaques. The former contains fine almost parallel lamellae of plagioclases which are in some cases bent and deformed. The extinction angle varies from $9^{\circ}-24^{\circ}$ or even more indicating albite or oligoclase composition of plagioclase.

Quartz is ubiquitous in all the rocks and shows strong undulatory extinction suggesting subsequent impress of strong deformation. Among the accessories apatite, tourmaline, opaques, epidote, zircon, etc. are common.

\section{Paragenesis of the mineral assemblages}

The petrographic characters described above suggest that the changes are partly related to dehydration and rehydration reactions, besides rapid heating by the magmatic intrusion. This is consistent with the view of other petrologists, viz Green (1963), Naggar and Atherton (1970) and others. The petrographic study has revealed the following mineral assemblages in the rocks:

\subsection{Pelitic and semi-pelitic}

(i) Chl-Ser-Mus-Op

(ii) Chl-Ser-Ep-Pl-Qtz-Op

(iii) Bio-Chl-Gt-Pl-Ep-Qtz

(iv) Bio-Mus-Gt-St-Pl-Ep-Qtz

(v) Bio-Gt-Fib-Pl-Qtz

(vi) Bio-Mus-Chl-Fib-Pl-Per-Qtz

(vii) Bio-Mus-St-Gt-Sill-Pl-Qtz

(viii) And-Bio-Chl-Mus-Gt-Fib-Pl-Qtz

(ix) And-Bio-Mus-Fib-Per- $( \pm \mathrm{Pl}, \mathrm{Mic})$

(x) And-Bio-Mus-Gt- $( \pm \mathrm{Pl}, \mathrm{Chl})$

(xi) And-Bio-Mus-Fib-Pl-Per-Qtz

(xii) And-Chl-Mus-Bio-Sill-Pl-Per- $( \pm$ Op)

In addition to these apatite, opaques, tourmaline, sphene, zircon etc. occur as accessory constituents.

\subsection{Quartzo-feldspathic}

(xiii) Mus-Bio-Pl-Mic-Qtz

(xiv) Bio-Pl-Mic-Ep-Sp-Qtz

(xv) Bio-Mus-Pl-Mic-Zo-Clzo-Qtz- $( \pm$ Per $)$

The chemical analyses of the phyllites and the hornfelses given in table 1 show no basic variation in their chemical composition. In the latter relatively higher silica and low alumina, in few samples, may be due to high quartz content in these rocks. Similarly 
a little variation in $\mathrm{K}_{2} \mathrm{O}$ and $\mathrm{Na}_{2} \mathrm{O}$ may be either due to variation in rock composition or related to alkali-metasomatism in the contact rocks, also pointed out by Compton $(1960)$ in the Santa Rosa area.

The mineral assemblages of the rocks of the area are depicted in AKF diagram and AFM projection (figures 4,5 ). The mineral points represent the ideal composition. In the AKF diagram (figure 4) the phyllite plots on the muscovite-chlorite join and the muscovite-biotite schist close to the ideal muscovite-biotite tie-line while the hornfelses plot in muscovite-biotite-almandine three phase field below the muscovite-almandine join demonstrating that the bulk composition of the rocks is in general not highly aluminous. On the other hand feldspathic schist/gneiss plot in the K-feldspar-biotitemuscovite field.

chlorite solid solution join whereas the biotite-bearing phyllite/schist lie in the chloritebiotite two phase field close to the chlorite solid solution tie-line (sample no. 6). The chemical composition of the hornfelses 1 plot in the alumino-silicate (A-apex)-biotitechlorite triangle and the sample nos. 3, 7 and 9 which are either devoid of or very poor in chlorite plot on or close to the A-apex-biotite join (figure 5B). Many hornfelses (table 1) contain greater number of phases than is expected to occur at equilibrium according to the phase rule viz Chl-Bio-And-Sill-Gt-Mus, Bio-Mus-Gt-St-Sill, And-Chl-Bio-MusSill and are thus incompatible with the topology of the AFM projection (figure 5B). Many such reports are available in literature showing that the pelitic rocks contain an extra phase in the $\mathrm{Al}_{2} \mathrm{O}_{3}-\mathrm{K}_{2} \mathrm{O}-\mathrm{FeO}-\mathrm{MgO}$ tetrahedron. Various possibilities have been discussed by Hietanen (1961), Woodland (1963), Green (1963) and others to explain the presence of an extra-phase in such assemblages. Green (1963) postulated that in thermal aureole due to rapid heating of the rocks mineral reactions proceed towards the formation of much less hydrous phases viz staurolite, cordierite and aluminum silicate from muscovite and chlorite and if all the $\mathrm{H}_{2} \mathrm{O}$ could not escape readily enough, these reactions would be incomplete and an extra phase may thus occur because of the decrease in variance of the system. Besides this garnet may occur as an extra phase either due to its refractory nature, zoning, $\mathrm{Mn} / \mathrm{Ca}$ content or overstepping of reaction may lead to metastable coexistence of a phase or the assemblage may represent disequilibrium.

Many petrologists have shown that almandine in the low-pressure metamorphism contains considerable amount of $\mathrm{Mn}$ or $\mathrm{Ca}$, hence stabilizing it outside the stability field of the equilibrium assemblages (Miyashiro 1953; Chinner 1962; Okrusch 1971; Lal and Ackermand 1981 and others). The Mn-content in the garnet of the area ranges from 2.18-2.81 showing a tendency to increase from periphery to core. This implies that the earlier garnet of the low grade regionally metamorphosed rock is probably somewhat higher in Mn-content than the later peripheral garnet. Moreover as the garnet is rich in almandine-content it may be occurring as an extra phase due to its refractory nature or zoning. The textural relation suggests that the garnet may have formed from chlorite and muscovite by the following reactions:

$$
\begin{aligned}
& \mathrm{Chl}+\mathrm{Mus}+\mathrm{Qtz} \rightleftharpoons \mathrm{Gt}+\mathrm{Bio}+\mathrm{H}_{2} \mathrm{O}, \quad \text { (Hollister 1969) } \\
& \mathrm{Chl}+\mathrm{Mus} \rightleftharpoons \mathrm{BiO}+\mathrm{Gt}+\mathrm{H}_{2} \mathrm{O} . \quad \text { (Naggar and Atherton 1970) }
\end{aligned}
$$

The formation of garnet from biotite, as suggested by Okrusch (1971) is not evident in the area. 


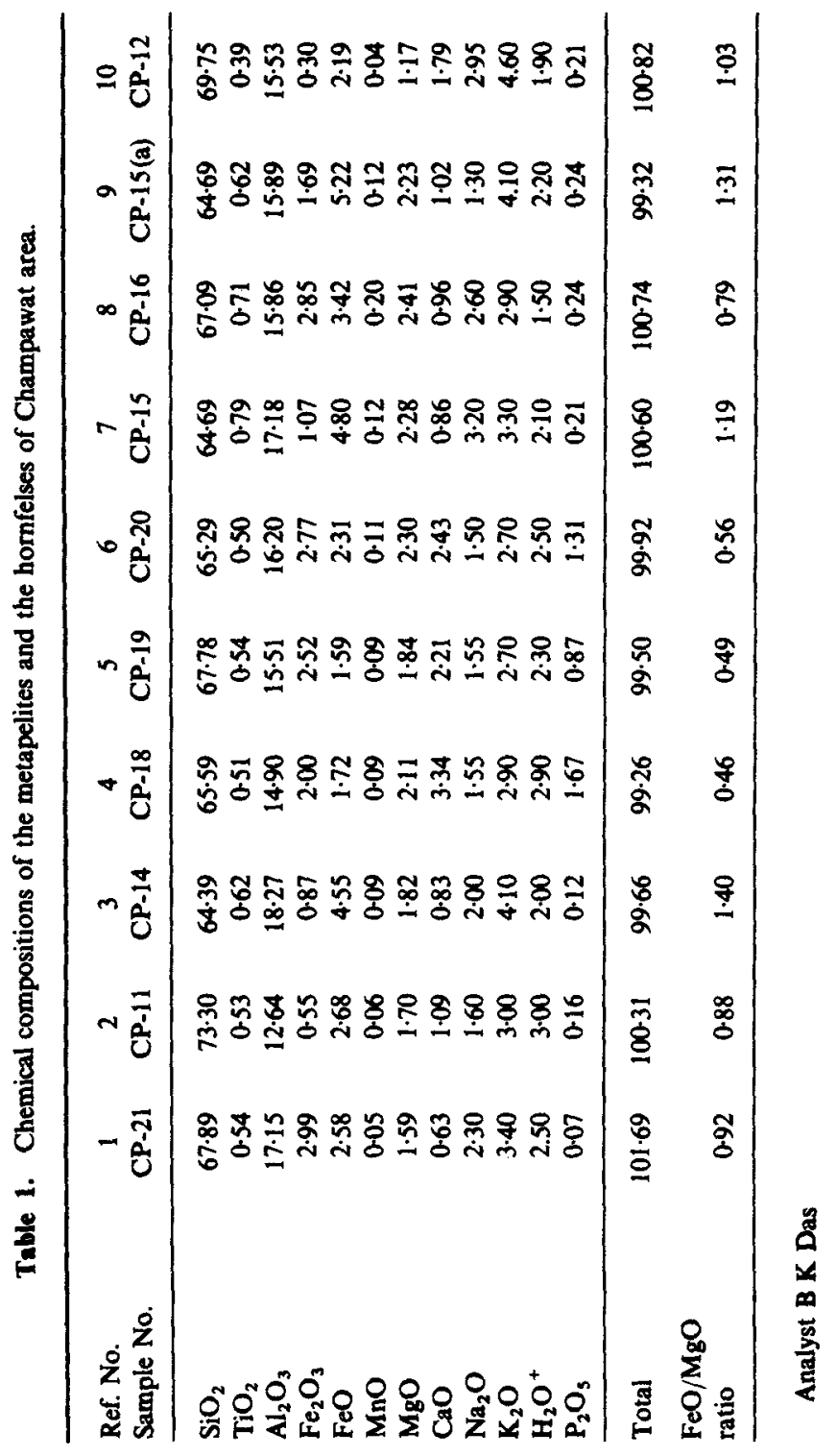




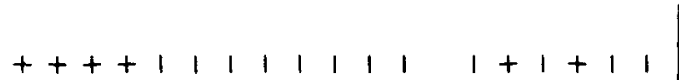

$$
\begin{aligned}
& t+1111+t|1| 1 \mid 1+t+11
\end{aligned}
$$

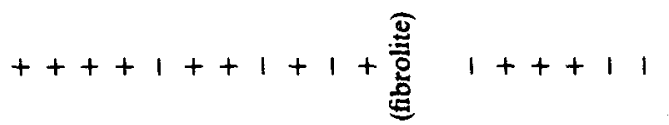

$$
\begin{aligned}
& +++1+++1++1++1++1 \\
& +++1+t+111+11+t+t \\
& ++1+1++111+11+t+1
\end{aligned}
$$

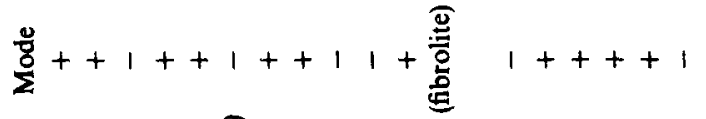

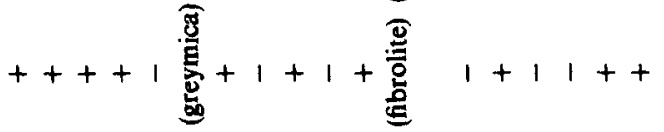

$$
\begin{aligned}
& +t 1+1++111111+1+11 \\
& ++1+++\begin{array}{lllllll}
1 & 1 & 1 & 1 & 1 & 1 & 1+t++ \\
+
\end{array}
\end{aligned}
$$

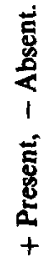




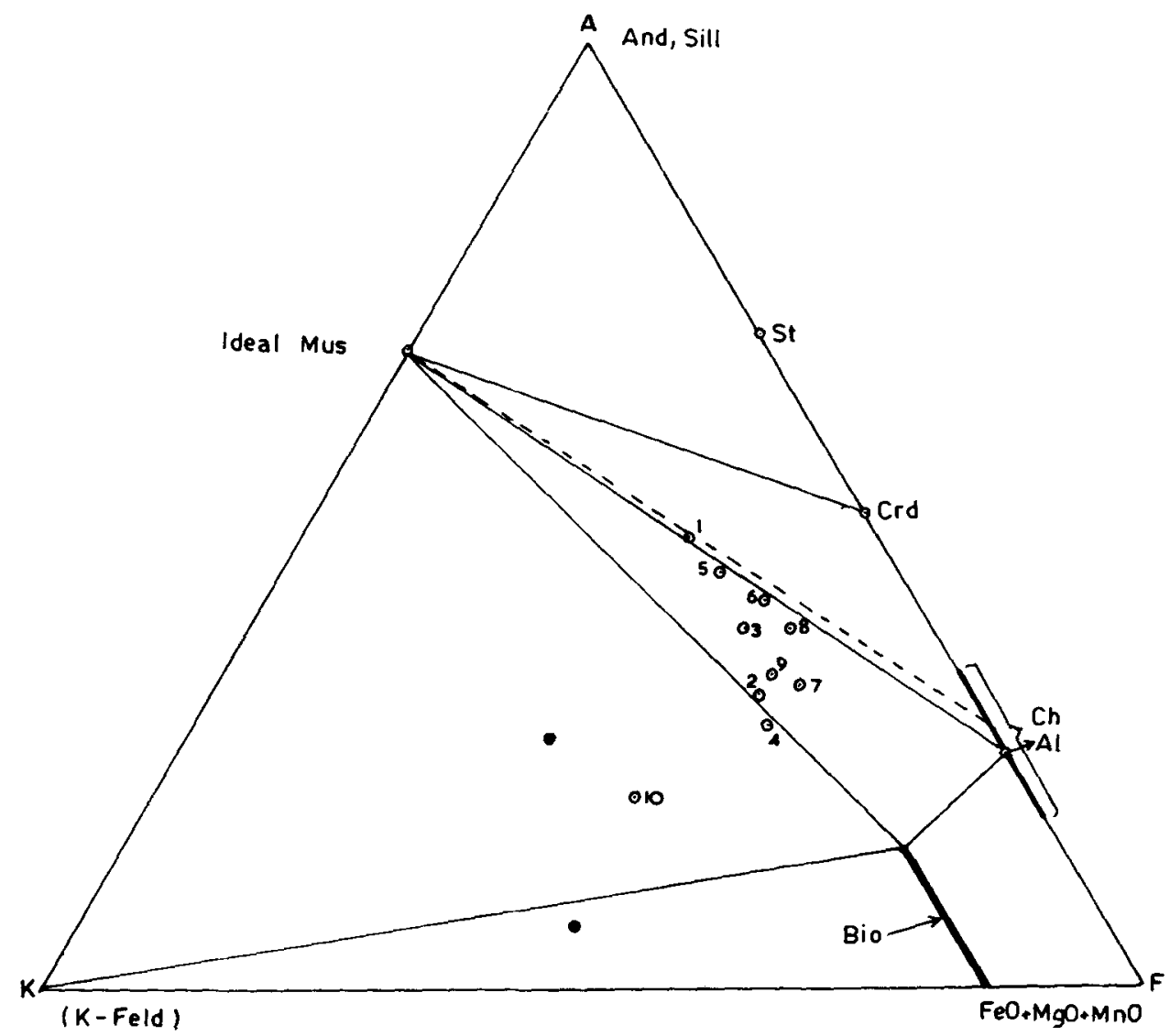

Figure 4. AKF diagram showing the plots of chemical composition of Champawat pelitic rocks (open circles). The mineral points represent the ideal composition. The plots of hornfelses lie in the three phase field Mus-Bio-Alm and that of phyllite plot on the Mus-Chljoin. The solid circles schematically depict the mineral assemblages.

Staurolite is not formed as a common phase except its scarce development in a mesh of white mica and the latter contains traces of relict biotite and opaques indicating that it has formed by the following rehydration reaction:

$$
31 \text { And }+4 \mathrm{Bio}+3 \mathrm{H}_{2} \mathrm{O} \rightleftharpoons 6 \mathrm{st}+4 \mathrm{Mus}+7 \mathrm{Qtz} \text {. }
$$

The general absence of staurolite in the hornfels of Champawat may be due to lower $\mathrm{Al}_{2} \mathrm{O}_{3} / \mathrm{FeO}+\mathrm{MgO}$ ratio which is evident from the AKF and AFM diagrams (figures 4, $5 b)$. In the former the bulk analyses plot below the muscovite-almandine join while the points which lie above this join generally contain staurolite. In the latter the rock composition plots are restricted to three phase And-Bio-Chl field.

Andalusite is a common phase occurring in most of the hornfelses. It is commonly reported from the outer most zone of a thermal aureole indicating relatively low temperature and probably more hydrous conditions which is followed by the appearance of cordierite and cordierite-sillimanite and/or $\mathrm{K}$-feldspar in the inner zones. On the other hand, in Donegal area, Pitcher and Read (1960) suggested low 

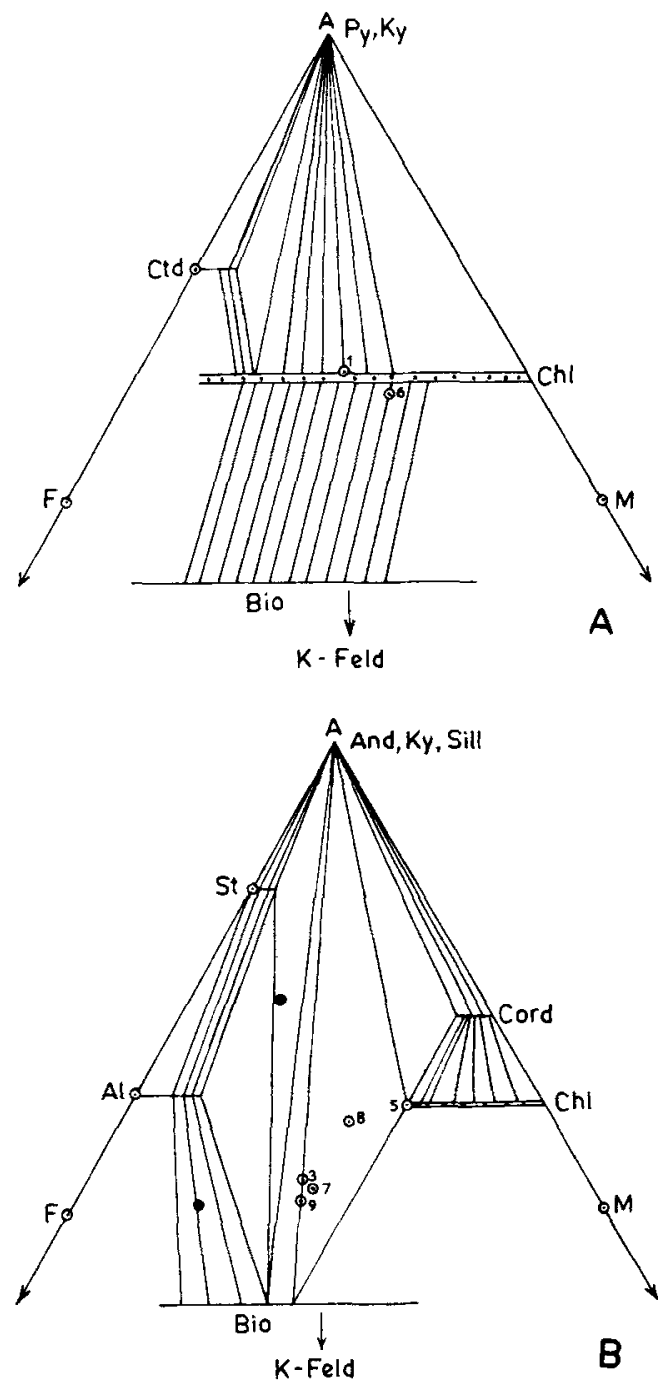

Figure 5. The Thompson's $A F M$ projection, $\left(A=\left(\mathrm{Al}_{2} \mathrm{O}_{3}+\mathrm{Fe}_{2} \mathrm{O}_{3}\right)-\left(3 \mathrm{~K}_{2} \mathrm{O}+\mathrm{Na}_{2} \mathrm{O}\right.\right.$ $+\mathrm{CaO}), \mathrm{F}=\mathrm{FeO}+\mathrm{MnO}$, and $\mathrm{M}=\mathrm{MgO}$, in mol \%) showing the mineral assemblages of the pelitic hornfelses of the Champawat area (open circles). The solid circles represent the mineral assemblages schematically.

temperature and low stress for its formation. This is consistent with the earlier view of Streckeisen (1938) who stated that staurolite-free andalusite assemblages form at lower pressure or at a higher partial pressure of water. The first appearance of andalusite with quartz in the upper greenschist or albite-epidote hornfels facies (Turner 1968) is shown at about $400^{\circ} \mathrm{C}$ from reaction of pyrophyllite (Kerrick 1968). The mineral assemblage and the chemistry of rocks (low-alumina) do not indicate its formation from 
pyrophyllite. On the other hand the textural relation suggests its formation from:

$$
\begin{aligned}
& \mathrm{Chl}+\mathrm{Mus}+\mathrm{Qtz} \rightleftharpoons \text { And }+\mathrm{Bio}+\mathrm{H}_{2} \mathrm{O}, \\
& \text { White mica }+\mathrm{Chl} \rightleftharpoons \text { And }+\mathrm{Bio}+\mathrm{Qtz}+\mathrm{H}_{2} \mathrm{O} .
\end{aligned}
$$

This is consistent with the view of Seki (1954) who stated that in the north-eastern Japan, andalusite is stable in the chlorite zone.

The absence of cordierite in the pelitic hornfelses of Champawat area is rather intriguing. It is a common mineral in the aureole rocks of the other areas of the world. According to Best and Weiss (1964) the absence of cordierite in muscovitic and some perthitic assemblages at Isabella may be on account of insufficient magnesian rocks whose bulk compositions would not fall in the cordierite stability field, or that cordierite was not a stable phase at the prevailing set of external variables, or both. As the bulk analyses of Isabella hornfels are not given, a comparison in this respect is not possible. However, the common occurrence of chlorite-andalusite-muscovite-bearing assemblage probably indicates that the composition field of the cordierite-bearing rocks is restricted towards lower $\mathrm{FeO} / \mathrm{MgO}$ side in the AFM projection (figure 5B), and as this ratio is high in the pelitic rocks of the area, cordierite is absent. The diagram also demonstrates that because of stable andalusite-biotite join, composition field of chlorite lies towards lower $\mathrm{FeO} / \mathrm{MgO}$ side of the projection. Therefore compositional constraint seems to be the main cause for its absence in the area. A similar situation has been noticed for the absence of cordierite in muscovite-bearing pelitic schist of Khetri copper belt of Rajasthan by Lal and Shukla (1975).

The fibrolite and sillimanite are also problematic in these rocks. The evidence of polymorphic transformation of andalusite to sillimanite is not very common and only in one specimen, from the contact of magmatic body sillimanite needles and prisms penetrate in adjacent andalusite and show replacive relation indicating resorption (figure $2 \mathrm{f}$ ). The fibrolite and sillimanite are mostly formed independently from biotite and less commonly from muscovite and their association with biotite as observed texturally may be due to epitaxial growth of sillimanite in Champawat (Chinner 1961). The typical occurrence of sillimanite in the area may be due to higher temperature conditions in proximity of magmatic body (Holdaway 1971). As the formation of fibrolite from andalusite requires large amount of overstepping which is not evident in the area and also not possible as the temperature gradient is not high, such transformation is not common. Moreover, in fine needles of sillimanite surrounding quartz, perthite, plagioclase and even andalusite, etc there is late sillimanite as described by Tozer (1955), Pitcher and Berger (1972) and others and in all probability related to metasomatic activity in the area.

\section{Metamorphic facies and physical conditions of metamorphism}

The regionally metamorphosed rocks of the area represent greenschist facies conditions of metamorphism (Turner 1968) but the contact metamorphic assemblages cause ambiguity because of very scarce epidote, absence of staurolite and cordierite and common occurrence of garnet and sillimanite. However, the presence of biotite, muscovite, chlorite, andalusite, fibrolite, plagioclase and perthite in the assemblages of hornfels may suggest hornblende-hornfels facies conditions of metamorphism (Turner 
1968). The greenschist facies rocks were subsequently superimposed by thermal metamorphism due to emplacement of magmatic body which caused rapid heating during which spongy garnet crystallized from the assemblage muscovite and chlorite rendering 'available' composition more aluminous (Atherton and Brotherton 1972). The rapid heating and low prevailing pressure gave rise to the formation of andalusite in the rocks. The textural evidence indicates that the new aureole minerals mainly grew directly from the ground-mass of quartz-muscovite-chlorite and/or biotite. The aluminium silicates did not form from one another whilst they grew from a series of dehydration reactions involving the layered minerals. The sillimanite and fibrolite usually formed independently of andalusite except in few cases.

Andalusite is a characteristic porphyroblastic mineral of pelitic hornfels of Champawat area which according to Turner (1968) may be used as a pressure index, limiting the probable pressure field of the hornblende-hornfels facies to less than about $3 \mathrm{~kb}$. Hirschberg and Winkler (1968) have shown on the basis of experimental data that almandine can form at $500^{\circ} \mathrm{C}$ at $4 \mathrm{~kb}$ and $600^{\circ} \mathrm{C}$ at $5 \mathrm{~kb}$ and that the pressure values may be lower by $2 \mathrm{~kb}$ if appreciable amount of spessartine component is present in garnet which is consistent with the opinion of other petrologists e.g. Miyashiro (1953). As mentioned earlier the Mn-content of garnet is not high in the hornfelses of the area, therefore a pressure condition of about $3 \mathrm{~kb}$ may be estimated. The coexistence of chlorite + quartz, chlorite + quartz + muscovite, chlorite + andalusite + quartz etc and the absence of cordierite suggests temperature of $550^{\circ} \mathrm{C}$ at $5 \mathrm{~kb} \mathrm{P}_{\mathrm{H}_{2} \mathrm{O}}$ and $500^{\circ} \mathrm{C}$ at $2 \mathrm{~kb}$ $P_{\mathrm{H}_{2} \mathrm{O}}$ as demonstrated experimentally by Fawcett and Yoder (1966). But some samples from the immediate contact of magmatic body contain well-crystallized sillimanite and/or fibrolite nucleating on mica, may indicate a higher temperature condition (Holdaway 1971). However, a stable coexistence of muscovite and quartz suggests that the breakdown temperature of these phases has not reached. Therefore the upper limit of temperature of about $600^{\circ} \mathrm{C}$ may be estimated for these rocks. It may therefore be concluded that a temperature of about $500 \pm 50^{\circ} \mathrm{C}$ approaching $600^{\circ}$ at pressure of about 2-3 kb may have reached during thermal metamorphism of Champawat area.

The general absence of thermal aureole around the main batholith may be due to erosion since the thermal aureole tend to be confined to roof portions of the country rock.

\section{Acknowledgements}

The author is grateful to Prof. R C Misra for his suggestions. He also wishes to place on record his thanks to the University Grants Commission, New Delhi, for financial assistance.

\section{References}

Atherton M P and Brotherton M S 1972 J. Geol. 203

Best M G and Weiss L F 1964 Am. Miner. 491240

Chinner G A 1961 J. Petrol. 2312

Chinner G A 1962 J. Petrol. 3316

Compton R R 1960 Bull. Geol. Soc. Am. 711383

Das B K and Singh C 1981 Bull. Indian Geol. Assoc. 1483 
Fawcett J J and Yoder H S 1966 Am. Miner. 51353

Gansser A 1964 Geology of the Himalayas (London: Wiley-Interscience)

Green J C 1963 Am. Miner. 48991

Hietanen A 1961 Finlande Comm. Geol. Bull. 3373

Hirschberg A and Winkler H G F 1968 Contrib. Miner. Petrol. 1817

Holdaway M J 1971 Am. J. Sci. 27197

Hollister L S 1969 Geol. Soc. Am. Bull. 802465

Kerrick D M 1968 Am. J. Sci. 266204

Kharkwal A D 1951 Q. J. Geol. Min. Soc. India 23135

Lal R K and Shukla R S 1975 N. Jb. Miner. Abh. 124294

Lal R K and Ackermand D 1981 N. Jb. Miner. Abh. 141161

Misra R C and Sharma R P 1967 J. Geol. Soc. India 3110

Miyashiro A 1953 Geochim. et Cosmochim Acta 4179

Naggar M H and Atherton M P 1970 J. Petrol. 11549

Okrusch M 1971 Contrib. Miner. Petrol. 321

Pitcher W S and Berger A R 1972 The geology of Donegal: A study of granite emplacement and unroofing (New York: Wiley-Interscience)

Pitcher W S and Read H H 1960 Q. J. Geol. Soc. London 1161

Seki Y 1954 Saitama Univ. Sci. Rep. Ser. B.Z. 309

Sharma R P and Awasthi D D 1980 Indian Miner. 2121

Streckeisen A 1938 Schweizer Min. Petrol. Mitt. 887

Tozer C F 1955 Geol. Mag. 92310

Turner F J 1968 Metamorphic petrology (New York: McGraw Hill)

Valdiya K S 1962 Indian Miner. 36

Valdiya K S 1980 Wadia Inst. Him. Geol., Dehradun

Woodland B G 1963 Am. J. Sci. 261354 